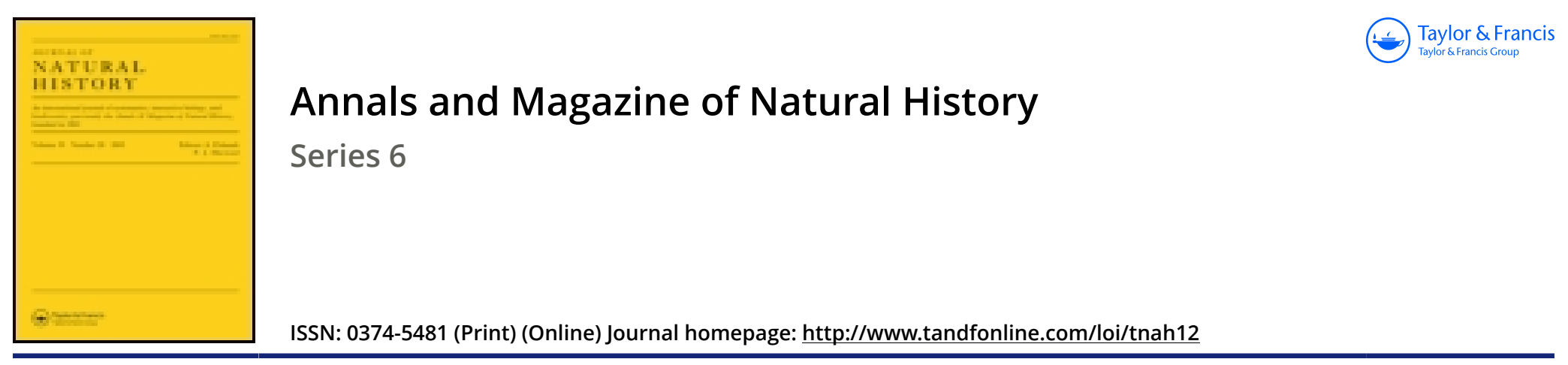

\title{
XLII._Additions to the shell-fauna of the Victoria Nyanza or Lake Oukéréwé
}

\section{Edgar A. Smith}

To cite this article: Edgar A. Smith (1892) XLII._Additions to the shell-fauna of the Victoria Nyanza or Lake Oukéréwé , Annals and Magazine of Natural History, 10:59, 380-383, DOI: 10.1080/00222939208677429

To link to this article: http://dx.doi.org/10.1080/00222939208677429

曲 Published online: 02 Oct 2009.

Submit your article to this journal $\sqsubset x$

Џ Article views: 3

Q View related articles $₫$

4 Citing articles: 1 View citing articles 진 
etiological school brings with it is therefore false; the true portion of it has long been known as physiology.

In spite of this it is of great importance to lay especial emphasis upon it; it was able to render our historic method considerably more profound, and must become an integral part of phylogenetic investigation. To bring it into a mutually exclusive opposition to the historic method, as has been done, is without justification. Without the idea of descent the structure of an animal body cannot be understood. One example will suffice. In the whalebone whales teeth appear in the earliest embryonic period. These do not cut the gum, are entirely functionless, and after some time, still in the embryo, are completely absorbed. Now how can we succeed in understanding this phenomenon by means of the mechanico-etiological method? Is not our want of a cause satisfied to a certain extent if, on the basis of phylogenetic investigation, we are able to prove that the germs of these teeth are inherited from ancestors of the whalebone whales, in which the teeth were functional, while in the existing whales, in consequence of an altered mode of life, they are replaced by more practical organs in the shape of the whalebone?

In conclusion I would emphasize the fact that I too am convinced that the processes which are termed vital force obey the same laws which dominate the inorganic world. I too behold in the introduction of a vital force, which is to us obscure and mysterious, only an unnecessary addition, and consider the tracing of life to physico-chemical laws, although not as a fact that has been proved, nevertheless as a scientitic postulate.

\section{XLII.-Additions to the Shell-Fauna of the Victoria Nyanza or Lake Oukéréwé. By EdGAR A. SMith.}

Since the publication of my report on the shells of this lake in the 'Annals' for last August I have discovered that Dr. E. von Martens a month or two previously had described five species from the same locality, namely one species of Limnoca, a Physa, and three species of Viviparus. The Physa is the species which in his former paper (SB. Gesell. nat. Freund. Berlin, 1879, p. 103) he considered might possibly belong to $P$. nyassana, Smith. 
The British Museum has recently obtained a small collection made by the Rev. E. Cyril Gordon at both the north and south shores of the lake. This series, consisting of eleven species, contains nine which are new to the Museum, four being also new to science. The finest species, belonging to the genus Ampullaria, hitherto unknown from the lake, is the largest of that group as yet recorded from the African continent, and the Sphcerium represents a genus which, besides being sparingly represented in Africa, is also new to the lake.

In addition to the above species Mr. Gordon also obtained the Atheria elliptica from the Nile at the Ripon Falls. This species was found at the southern part of Lake Victoria by the late Bishop Hannington.

I. Additional Species described by Dr. E. von Martens.

1. Limnaa nyansa, Martens.

Limnoea nyansa, Martens, SB. Gesell. nat. Freund. Berlin, 1892, no. 2, p. 16.

Hab. W' $\mathrm{W}^{T}$ st shore at Bukoba and Towalio.

2. Physa trigona, Martens.

Physa trigona, Martens, l. c. p. 17.

Hab. Bukome in South-west Creek (Martens); North end (Gordon).

3. Viviparus phthinotropis, Martens.

Viviparus phthinotropis, Martens, l. c. p. 17.

Mab. Njamagolso, south-west part of lake.

'This species may be the same as my $V$. victorice.

4. Viviparus trochlearis, Martens.

Viviparus trochlears, Martens, l. c. p. 18.

$H a b$. Sirwa Island.

5. Viviparus costulatus, Martens.

Tivaparus costulatus, Martens, l. e. p. 18.

Hab. Kassarasi Island. 
IJ. New Species discovered by Rev. E. Cyril Gordon.

\section{Ampullaria nyanze.}

Testa maxima, globosa, late umbilicata, solida, ponderosa, epidermide olivaceo-fusca induta ; anfractus 6 , primi tres erosi, sequentes convexi, incrementi lineis obliquis mediocriter fortibus striisque spiralibus minutis confertissimis sculpti, ultimus infra periostracum zonis numerosis angustis obscuris pictus; apertura inverse auriformis, luteo-albida, zonis spiralibus purpureo-fuscis, præcipue ad marginem conspicuis, obscure picta, longit. totius $\frac{5}{7}$ subæquans ; peristoma haud incrassatum, intus plus minus flavescens, purpureo-fusco maculatum, margine columellari obliquo, mediocriter reflexo, superne flavo, infra purpureo-fusco tincto.

Alt. 115 millim., diam. maj. 108, min. 85; apertura 80 longa, 52 lata.

Hab. A creek, commonly called Jordan's Nullah, at the south end of the lake.

This species is the largest recorded from any part of Africa. Ampullaria charmesiana, Billotte ${ }^{*}$, is nearly as large, and occurs in the Nile above Gondokoro; that species, however, is longitudinally costulate, has a narrower aperture, and the peristome is strongly thickened within and tinted with orange. On the contrary, A.nyanze has a thin peristome without any thickening within, and is conspicuously blotched with purplebrown by the terminations of the spiral zones. The surtace of this species is very minutely spirally striated, a feature also occurring in $A$. speciosa, another large form from eastern Africa. 'That species, like $A$. charmesiana, has an orange lip with an internal thickening. It has a more depressed spire and the whorls are more or less impressed or channelled above at the suture.

Reeves's tigure of $A$. erythrostoma (Conch. Icon. pl. xiii. fig. 59), if the three apical whorls be concealed, gives a fair idea of the proportions of the present species.

\section{Ampullaria Gordoni.}

Testa globosa, anguste perforata, zonis numerosis angustis saturate fuscis epidermide olivacea subobscuratis cincta; anfractus 5, celeriter crescentes, mediocriter convexi, sutura lineari flava sejuncti, plus minus minute et spiraliter striati, nltimus magnus, incrementi lineis obliquis sculptus; apertura magna, longit. totius $\frac{4}{5}$ fere æquans, intus purpurea zonis externis indistincte notata;

* Bull. Soc. Mal. France, 1885, vol. ii. p. 106. 
peristoma tenue, intus nigro-purpureum, inferne leviter effusum, ad columellam vix reflexum, marginibus callo plus minus atropurpureo junctis.

Alt. 54 millim., diam. maj. 52, min. 37 ; apertura 44 longa, 27 lata.

Hab. Victoria Nyanza (south end ?).

The single shell which I have named after Mr. Gordon does not appear to be the young of $A$. nyanzw. It is much more narrowly umbilicated, has a shorter spire and a larger aperture. The latter is of a much darker colour, the columella and the inside of the outer lip are purplish black, and the external spiral narrow zones are more distinct.

\section{Planorbis victorice.}

Testa inferne late et profunde umbilicata, supra minus profunde et angustius excavata, mediocriter inflata, lineis incrementi obliquis striata, olivacea ; anfractus 3-4, celeriter crescentes, ultimus superne et ad peripheriam rotundatus, infra circa umbilicum compresse angulatus vel carinatus, antice subdescendens; apertura mediocriter magna, fusca, superne lata, inferne angustata, recedens : peristoma (lateraliter visum) obliquum.

Diam. maj. 8 millim., min. 6, alt. 4.

$H a b$. North end of the lake.

This species apparently is distinct from Pl. choanomphalus, Martens, also from Lake Victoria. It has no upper or peripherial angle, and the lower side is more deeply umbilicated than the upper.

\section{Sphcerium nyanza.}

Testa rotunde ovata, solidiuscula, mediocriter globosa, straminea, umbones versus leviter erosa, subæquilateralis, striis concentricis tenuibus seulpta; latns anticum rotundatum, posticum paulo latius; umbones parum prominentes, obtusi, mediani; dentes cardinales mediocres, laterales validi; pagina interna albida.

Longit. 7 millim., alt. 6 , diam. $4 \frac{1}{3}$.

Hab. North end of the lake.

This species is of rather solid texture, of a straw-colour, and only faintly striated. The lateral teeth are strongly developed for so small a shell. S. capense, Krauss, is thinner and has a more feeble dentition. 